Has the CSR engagement of electrical companies had an effect on their performance? A closer look at the environment

\begin{tabular}{|r|l|}
\hline Journal: & Business Strategy and the Environment \\
\hline Manuscript ID: & BSE-13-0204.R2 \\
\hline Wiley - Manuscript type: & Research Article \\
\hline Keywords: & CSR, financial performance, environment, electrical companies \\
\hline \multicolumn{2}{l}{} \\
\end{tabular}

SCHOLARONE ${ }^{\mathrm{m}}$

Manuscripts 


\title{
Has the CSR engagement of electrical companies had an effect on their performance? A closer look at the environment
}

\begin{abstract}
:
Even though electrical companies attain a top ranking in the publication of CSR reports, they are often accused of "green-washing" due to their bad environmental reputation. The current economic crisis is testing their real CSR commitment more than ever, especially when this goes beyond its economic consequences.
\end{abstract}

Based on a worldwide sample of electrical companies, we are going to study why companies are being socially responsible. We wish to know if it is due to the impact on the firms' performance or whether there are other motives (legitimation, improving their reputation) that lead companies to carry out these practices. We will also consider if it changes across the kind of CSR actions considered.

The results show that there is an economic justification beyond the socially responsible behaviour of the electrical companies. Additionally, most kinds of CSR actions (community, diversity, corporate governance, product responsibility) are also carried out looking for economic rewards. However, the CSR actions oriented to the environment are mainly motivated by their need to improve their image and reverse their negative impact.

\section{KEY WORDS:}

CSR, financial performance, environment, electrical companies. 


\section{Introduction}

The evolution of Corporate Social Responsibility (CSR) in terms of importance and significance over the last decades is undeniable (Schultz and Wehmeier, 2010). It has changed from being an irrelevant or fashionable idea to one of the most widely accepted concepts in the business world (Lee, 2008).

Even though carrying out CSR practices has become a requirement to be able to operate (Peloza, 2006), their widespread use makes researchers consider the reasons why companies are increasingly more engaged with CSR. That is, if this is due to pure altruism or if, in contrast, they are looking for legitimacy or an economic reward according to the arguments of the Legitimacy (Deegan, 2002) and Stakeholder Theories (Freeman, 1984).

Although many researchers have tried to answer if being socially responsible has an effect on a company's performance (Orlitzky et al., 2003; Allouche and Laroche, 2005; Wu, 2006; Fifka, 2013), the results found have not been totally conclusive. This is mainly due to the different approaches (linear vs non-linear), samples, and the CSR/performance measures used (Davidson and Worrell, 1990; Ruf et al., 2001).

Notwithstanding, many researchers (Waddock and Graves, 1997; Margolis and Walsh, 2003) have shown the determinant role that the industry plays in this relationship. They argue that the use of cross-sectional samples could mean the compensation or overlapping of the results, and, therefore, explain the lack of general conclusions. These are based on two arguments. Firstly, the kind of CSR actions carried out by companies depends on their stakeholders' pressures. This would be similar in the case of firms from the same industry (Patten, 2002). Secondly, the opportunity to get financial outcomes from their CSR actions are likely to be determined by industry-specific factors (Endrikat et al., 2014).

Despite the convenience of carrying out studies in specific industries that may clarify the relationship between CSR and Financial Performance (FP) (Griffin and Mahon; 1997; Rowley and Berman, 2000), this has not been extensively investigated in the most controversial or socially/environmentally sensitive sectors. While there are few articles focused on some of the most socially sensitive sectors, such as banks (Pérez-Ruiz and Rodríguez-Bosque, 2012; Escobar and Miras, 2013), and alcohol, tobacco and weapons (Cai et al., 2012), this relationship has not been analyzsd in depth in environmentally sensitive sectors.

The electric utilities have a high environmental impact derived from the generation of electricity energy (Hackston and Milne, 1996; Deegan and Gordon, 1996; Pätäri et al., 2012). This makes them be considered as "a dirty sector" (Mio, 2010; Kerckhoffs and Wilde-Ramsing, 2010). Likewise, they have a strategic and determinant role in the evolution of developed and developing economies all over the world (Sutton, 2007). Hence, we consider it interesting to 
study how this relationship between CSR and FP is in one of the most environmentally-concerned sectors.

Moreover, electrical companies have to face the dilemma of disclosing information about CSR, since it could be seen such as an attempt at "windowdressing" or "green-washing" (Vries et al., 2013), legitimising (Deegan, 2002) or improving their reputation (Melo and Garrido-Morgado, 2012), instead of being a reflection of a real engagement (altruistic) with these issues.

Consecuently, it is crucial for researchers and society at large to know what the motivations of the CSR engagement of the electricity companies are. In this sense, we could study if there are economic motivations beyond their socially responsible behaviour or not.

Within the general debate about causality in the CSR-FP relationship (Salzmann et al., 2005), we are going to consider the curvilinear approach (Marom, 2006; Barnett and Salomon, 2012). This is because considering the high level of CSR commitment in the electrical sector (Alonso-Almeida et al., 2013) could be a better attempt at understanding whether there is an impact of CSR actions on the performance of the companies (Simpson and Kohers, 2002).

Nevertheless, several researchers are calling into question the suitability of using a single construct to measure CSR (Marom, 2006; Peloza, 2009), since it is the result of the agreggation of several unrelated aspects (Rowley and Berman, 2000), such as the environment, the community, diversity, employment, product responsibility, human rights and corporate governance (CSR dimensions according to $\mathrm{KLD}^{1}$ ). In this sense, companies from the same sector are going to focus their CSR efforts on the same aspects or dimensions according to their activity and their stakeholders' pressures (Patten, 2002). Hence, they are pointing out the need to also study socially responsible actions considering each different aspect or dimension involved.

Therefore, it is important as well to analyse whether each different CSR dimension has a relationship with corporate performance in order to understand if the motivations for its being carried out are the same. This is especially the case for environmental actions, due to the peculiarities of the electrical industry already outlined.

Regarding the effect of environmentally-responsible actions on corporate performance, traditionally it had been negatively supported by the Trade-Off hypothesis (Friedman, 1970). However, from a revisionist point of view, a positive and a curvilinear relationship have been suggested (Fujii et al., 2013), in consideration of the Win-Win Hypothesis (Porter and Van der Linde, 1995). This defends that environmentally responsible actions can produce cost savings through improving the efficiency and reducing waste and risks (Lankoski, 2008).

\footnotetext{
${ }^{1}$ KLD (Kinder, Lyderberg and Domini Stats Database). This is one of the most accepted databases for CSR measures.
} 
Therefore, this paper has a double aim. On the one hand, we would like to know if the CSR actions carried out by electrical companies are looking for an economic reward. On the other hand, we want to analyse whether the CSR-FP relationship changes if we study each CSR dimension, in particular that which is related to the environment.

We use an international sample (26 countries) which is composed of 89 electrical companies indexed in the stock markets of each country. We have chosen the period between 2008 and 2011 because the current financial crisis provides a very good opportunity to test real CSR motivations, due to there being less resources available (Ducassy, 2013). Our data are provided by the ASSET4 and Datastream databases.

According to the results, we find that CSR actions have an influence on the FP of the electrical companies. This is explained by a U-shaped curve. So, there is an economic justification behind the highly-extraordinary behaviours although standard actions are not as well rewarded. This could be because companies in the electrical industry are highly committed to CSR and, consequently, they are only rewarded when their behaviour is exceptional.

When we study the relationship between the CSR dimensions and FP, we realise that each of them shows a different impact or even no influence.

In this sense, the results report that actions oriented towards the environment do not show any relationship with corporate performance. This indicates that the motivations for their being carried out by the electrical companies are more related to their need to legitimise, to altruism or to be able to compete, although the high cost of being committed to the environment cannot be forgotten. Regarding the other CSR dimensions, the Community, Diversity, Corporate Governance and Product Responsibility are motivated by their financial rewards. However, the Employment dimension presents a lack of a relationship with the FP, therefore the motives behind them are more related to their concern with the current situation.

The paper is organised as follows. In Section 2, we focus on the debate about the different approaches that try to explain the CSR-FP relationship. In Section 3 , we look more closely at the sample and variables used as well as the methodologies employed. Section 4 presents the results of our study and the discussion. Finally, in Section 5 we show the conclusions, the limitations of the study and some of the lines of investigation which remain open.

\section{Theoretical framework}

Although the idea that firms have some responsibilities towards society beyond that of making profits for their owners has been around for hundreds of years (Carroll and Shabana, 2010), only at the end of the last century did CSR become a reality in business and one of the determinant factors which have been taken into account in decision-making (Garriga and Melé, 2004). 
Given its current relevance, many researchers (Brammer and Millington, 2005, Fernandez and Luna, 2007; Beurden and Gössling, 2008; Fifka, 2013) have wondered whether socially responsible behaviour involves some extra benefits apart from being able to compete in the current business environment (Martínez-Ferrero et al., 2013).

Empirical research about the relationship between CSR and FP started at the beginning of the 1970s (Moskowitz, 1972). Even though almost forty years have passed and there have been a large number of articles written about it, the results continue being heterogeneous (Orlitzky et al., 2003; Allouche and Laroche, 2005; Wu, 2006). This does not allow a conclusion about the direction of the causality (Salzmann et al., 2005) or about the mathematical sign of the relationship (Preston and O'Bannon, 1997).

Therefore, there has been much discussion in the literature (Davidson and Worrell, 1990; Ruf et al., 2001; Godfrey and Hatch, 2007) concerning what the possible causes for those empirical differences are. Most researchers highlight that there is not a unique theoretical framework to explain the relationship between CSR and FP.

Since the aim of this article is to study whether their CSR actions have an influence on the performance of the electrical companies, we focus on the Hypotheses or Theories which try to explain them. The traditional group of theories which defend the linear influence of CSR on FP (Preston and O'Bannon, 1996) are: the Social Impact Hypothesis and the Trade-off Hypothesis (Figure 1). On the one hand, the Social Impact Hypothesis (Freeman, 1984) assumed that the coincidence between the expectations of stakeholders and what the company gives them involved an increase in the performance of firms. However, the Trade-off Hypothesis (Friedman, 1970) stated that the costs of carrying out CSR actions are higher than the profits produced. This is putting them at a disadvantage when compared to other firms.

However, according to Simpson and Kohers (2002), the linear approach fails in its aim to give a complete explanation of the CSR-FP relationship, because in some cases an explanation could be the Social Impact Hypothesis and the Trade-off Hypothesis at the same time. This is why they revealed the need for a theoretical framework which allows us to have a better understanding of this behaviour.

In response to that demand, some researchers have focused on demonstrating that there is not a linear relationship but rather one which is curvilinear (Figure 2). Nevertheless, there is no agreement about if it is an inverted U-shaped relationship (Marom, 2006) or a U-shaped relationship (Barnett and Salomon, 2012).

Marom (2006) and Lankoski (2008) put together the two previous hypotheses and stated that, at the beginning, the satisfaction of the stakeholders' needs means an increase in the performance of the organisations (Social Impact Hypothesis). Later, however the costs of the social output are emphasised and reduce the performance (Trade-Off Hypothesis). This means that the more 
socially responsible the company is, the more profitable it is up to a peak from which the increases in CSR are followed by decreases of performance.

In contrast, Barnett and Salomon (2012) defended that the first part of the curve should have a downward slope, due to the high cost of starting to carry out CSR practices. Nevertheless, this slope goes upwards when the different stakeholders realise and value them (at that point the incomes exceed the costs). So, according to them, this is a U-shaped relationship.

Companies in the electrical industry are widely recognised as being top-ranking in publishing CSR or sustainability reports (Alonso-Almeida, 2013). This is a reflection of their high engagement with the CSR approach. This brings about being committed to CSR having become a requirement in the sector if companies do not want to have major negative effects on their performance (Margolis and Walsh, 2003). Considering this evidence, we predict that:

H1: The impact that CSR actions have on the FP of the electrical companies is explained by a U-shaped curve.

Additionally, it has been pointed out that a company's CSR policy is composed of several social outputs - each having diverse implications for the different stakeholders- and the great importance of the stakeholder management policies (Marom, 2006). In this sense, both approaches emphasise that each firm should identify those more economically worthwhile stakeholders and focus its CSR activity on them. Therefore, we are going to test the relationship, considering the different CSR dimensions in order to know if each of them has financial returns. In accordance with Barnett and Salomon's (2012) and Michelon et al.'s (2013) articles, the most used CSR disaggregate measures are the seven dimensions identified by KLD: (1) community, (2) diversity, (3) employment, (4) product responsibility, (5) environment, (6) corporate governance and (7) human rights.

In this regard, empirical evidence cannot be found in the literature about what is the best approach which explains the effect that each CSR dimension has on the firm's performance for multi-sectorial samples.

Regarding the environmental variable, its relationship with corporate performance has been extensively studied, supported by traditional (Trade-Off Hypothesis-Friedman, 1970) and revisionist theoretical framework (Fujii et al., 2013). This revisionist point of view defends that the profits may exceed the costs based on the Win-Win hypothesis (Porter and Van der Linde, 1995) since actions oriented to the environment can produce cost savings through improving the efficiency and reducing waste and risks (Lankoski, 2008). This involves both the positive linear and the curvilinear approaches (U-shaped and inverted U-shaped).

The previous evidence shows an effect of this kind of actions on the performance. Some of them present a linear impact (Molina-Azorín et al., 2009; Pérez-Calderón et al., 2011; Guenster et al. 2011) and others a curvilinear 
relationship (Wagner et al., 2002; Schaltegger and Synnestvedt, 2002; Dawkings and Fras, 2011; Fujii et al., 2013).

However, due to the singularity of this industry (Deegan and Gordon, 1996; Mio, 2010; Pätäri et al., 2012) and the accusations of carrying out environmental friendly actions to improve their reputation (Vries et al., 2013), we expect that:

$\mathrm{H} 2 \mathrm{a}$ : The environmental actions do not have an influence on the financial performance of the company.

Concerning to the other CSR dimensions (Community, Diversity, Employment and Corporate Governance), we can find in the literature those who also support the linear - diversity (Francoeur et al., 2008; Adams and Ferreira, 2009), employment (Deniz-Deniz and De Saa-Perez, 2003), community (Brammer and Millington, 2005; Cabeza-Garcia et al., 2010) and corporate governance (Core et al., 1999)- and the curvilinear approach -diversity (Ushaped- Capar and Kataba, 2003), employment (U-shaped- Sturman, 2003), corporate governance (inverted U-shaped- Andrés and Vallelado, 2008) and community (inverted u-shaped-Wang et al., 2008).

Most empirical evidence found in multi-sectional samples shows a relationship between these dimensions and corporate performance. Moreover, no evidence has been found in the literature about that these relationships having to differ if the focus is on the electrical industry. Therefore, as we can predict that all these dimensions show an impact on the performance, we state the following hypotheses:

$\mathrm{H} 2 \mathrm{~b}$ : The diversity actions have an influence on the financial performance of the company.

H2c: The employment actions have an influence on the financial performance of the company.

$\mathrm{H} 2 \mathrm{~d}$ : The corporate governance actions have an influence on the financial performance of the company.

H2e: The community actions have an influence on the financial performance of the company.

\section{Methodology.}

\subsection{Sample.}

The sample is composed of companies from the electrical industry which operate worldwide and are listed in the stock markets of 26 different countries. Finally, we found 89 firms $^{2}$ for the period studied 2008-2011.

\footnotetext{
${ }^{2}$ The full list of companies is available in Appendix 1
} 
The Social Responsibility data were provided by the ASSET4 database. This has already been used for this purpose by loannou and Serafeim (2012), due to their being much employed by investors to build their sustainability reports. It provides a collection of indicators ${ }^{3}$ (valued from 0 to 100) organised into four pillars: Social Scores, Environmental Scores, Corporate Governance Scores and, finally, Economic Scores. Additionally, the financial data were provided by the DataStream database, one of the largest databases of companies' financial and non-financial data.

\section{Dependent variable}

According to the evidence found by Orliztky et al., (2003) and Wu (2006), the accounting measures are those which better reflect the performance-return of the CSR actions, and, especially, the Return on Assets ratio (ROA). We are going to use the current ROA since the attempts to demonstrate that there is a time lag have not been successful (Orliztky et al., 2003).

\section{Independent variable}

Most articles use an aggregated CSR measure or index based on some of the seven areas of stakeholder management ranked by KLD. While Waddock and Graves (1997) proposed giving different weights to the dimensions in accordance with importance (subjective academic opinions - CSR_nw below) ${ }^{4}$, others suggested assigning equal importance to all the dimensions (Hillman and Keim, 2001; Waldman et al, 2006; Ioannou and Serafeim, 2012).

However, different equal-weights indices could be found in the literature, depending on the number of dimensions included. Thereby, we can see indices which include only two dimensions - social and environment issues, CSR_2 below- (Ioannou and Serafeim, 2012); others (Bird et al., 2007), which consider the five dimensions related to primary stakeholders according to Clarkson (1995) -community, diversity, employment, product responsibility, environment; CSR_ 5 below- or, finally, Kang et al. (2010), among others, which take into account the seven areas identified by KLD -community, diversity, employment, product responsibility, environment, human rights and corporate governance; CSR_7.

Therefore, we are going to consider these four aggregated CSR measures:

CSR_nw: $0.142^{*}$ Environment $+0.148^{*}$ Community $+0.089^{*}$ Diversity $+0.168^{\star}$ Employee + $0.154^{\star}$ Product_Responsibility.

CSR_2: $0.5^{\star}$ Social Score $+0.5^{*}$ Environmental Score.

CSR_5: (Environment+Community+Diversity+Employee+Product_Responsibility)/5

\footnotetext{
${ }^{3}$ The full list of the social indicators provided by the database is in Appendix 2.

${ }^{4}$ According to Waddock and Graves (1997) the weights should be: Employees (0.168), Product (0.154), Community (0.148), Environment (0.142), Treatment of women and minorities (0.136), Nuclear power (0.0089), Military contracts $(0.086)$, South Africa (0.076).
} 
CSR_7:(Environment+Community+Diversity+Employee+Product_Responsibility+Human Rights+Corporate Governance)/7

Additionally, since one of our aims is to identify the return on the actions made to the different stakeholders, it is also necessary to use disaggregated measures (Inoue and Lee, 2011; Michelon et al., 2013) to study the effects of the seven dimensions of CSR on the FP.

\section{Control variables}

Moreover, we have included several control variables related to the activity of the company, such as the size, the leverage level and the performance of the previous year (to control endogeneity) based on the previous findings. The company size is important because larger firms are more likely to carry out sustainability behaviours (McWilliams and Siegel, 2001; Surroca et al., 2010). This was measured by the logarithm of the total sales (Inoue and Lee, 2011). The company's level of risk tolerance is reflected in their managers' attitudes towards CSR actions, especially to elicit savings, incurring future or present costs and building or destroying markets (Waddock and Graves, 1997). This is measured by the leverage ratio.

Additionally, we control our model by three measures which depend on the country of origin of each company. Two of them are related to the legal enforcement of the sustainability reports, and the third one to the market. Firstly, we included a "report" variable which indicates if the company has to compulsorily report CSR information ${ }^{5}$. That is, if the sustainability or CSR report is mandatory or voluntary for them (dummy variable) ${ }^{6}$ due to the different patterns identified (Gray et al., 2001). In this sense, in many countries it is even mandatory to publish a CSR report for the main companies which are in their stock indexes (Alonso-Almeida et al., 2013). The advantages or disadvantages of the mandatory publication of CSR reports are not completely clear (Mobus, 2005). This could be good since each company has to reveal what they are really doing for society. On the other hand, having to disclose about something that is voluntary could be contradictory.

Furthermore, taking into account that $\mathrm{GRI}^{7}$ reporting guidelines had published an adaptative supplement for electric utilities companies in 2009 , it is interesting to control if there is any specific adaptation in the regulation for that sector in each country due its specific characteristics (regardless of it being mandatory or voluntary). Therefore, we have introduced this "special regulation" variable (dummy) .

\footnotetext{
${ }^{5}$ In "Carrots and Sticks. Sustainability reporting policies worldwide - today's best practice, tomorrow's trends" KPMG (2013), there is a detailed list of all the CSR regulation across all the countries.

${ }^{6}$ Dummy variables: 0 for voluntary and 1 for mandatory reports; 0 for no adaptation and 1 for specific adaptation; 0 for monopoly and 1 for no monopoly.

${ }^{7}$ Global Reporting Initiative.
} 
Finally, we include a "monopoly" variable, since many electric companies operate as a monopoly in their countries ${ }^{6}$. This is in order to control if there are some differences between them and those firms which operate in free markets or in oligopolies because of the intensity of the competition affecting the firms' performance (McWilliams and Siegel, 2000). To measure this, we are going to analyse all the electrical companies included in each stock market to see if they have to compete with others or not.

\subsection{Statistical Techniques}

To achieve our aims, we are going to use two different methodologies. Firstly, we are going to predict the score of the different dimensions that we could not take directly from ASSET4 (Community, Diversity, Employment, Product Responsibility and Human Rights) using PLS methodology (Partial Least Square) because we have the scores of different indicators for each CSR dimension (Appendix 2). Once we have the dimensions scores, we have constructed the different CSR aggregate measures, and, finally, we estimate several panel data regression models.

\section{Prediction of Dimension Scores by PLS}

Structural equation modelling (SEM) is a multivariate technique which combines aspects of multiple regression and factor analysis to simultaneously estimate a series of interrelated dependence relationships. The data analysis through SEM has expanded rapidly in recent years in many fields of social sciences but not in the accounting field (Lee et al., 2011), due to a certain reluctance of researchers.

According to Roldán and Sánchez-Franco (2012) SEM analysis can be carried out through two different statistical techniques: covariance-based methods (LISREL, AMOS) and variance-based methods (PLS). Taking into account that our aim is to predict the dimensions' scores, PLS is more suitable (Chin, 2010).

According to Lee et al. (2011), in order to predict the value of the dimensions, the PLS algorithm is based on two matters: the indicators and the relationship of the dimensions with the financial measure in the model. This process has three different stages, although we are only going to focus on stage 1 (Figure 3).

The dimensions have been built by the consideration of the indicators provided by ASSET4 for each dimension as formative indicators. This is why we have to carry out several tests of collinearity between the indicators included in each dimension to remove those which reveal this problem (FIV>30 and two or more correlations over 0.5). The eliminated indicators are crossed out in Appendix 2.

Once this was solved, the programme gave us the predicted scores for each dimension. These allow us to form the aggregated measures. 


\section{Data Panel Regressions}

We are going to estimate random effects models since we are not interested in the company effect, assuming that the variation across entities is random. Therefore, we estimate two models for testing the linear relationship and two models for the curvilinear one:

(1) ROA $_{t}=\beta_{1}+\beta_{2}$ Aggregated CSR $\mathrm{CS}_{\mathrm{t}}+\beta_{3}$ Ln Sales $t+\beta_{4}$ Leverage $_{t}+\beta_{5}$ Report $_{t}+\beta_{6}$ Special_Regulation $n_{t}+\beta_{7}$ Monopoly $+\beta_{8} R_{\text {ROA }}+\varepsilon$

(2) ROA $_{t}=\beta_{1}+\beta_{2}$ Environment $_{t}+\beta_{3}$ Community $_{t}+\beta_{4}$ Diversity $_{t}+\beta_{5}$ Employment $_{t}+\beta_{6}$ Product_Responsibility ${ }_{t}+\beta_{7}$ Human_Rights $t+\beta_{8}$ Corporate Governance ${ }_{t}+\beta_{9} L n$ Sales $_{t}+\beta_{10}$ Leverage $_{t}+\beta_{11}$ Report $_{t}+\beta_{12}$ Special_Regulation $_{t}+\beta_{7}$ Monopoly $+\beta_{8}$ $\mathrm{ROA}_{\mathrm{t}-1}+\varepsilon$

(3) ROA $_{t}=\beta_{1}+\beta_{2}$ Aggregated $\mathrm{CSR}_{\mathrm{t}}+\beta_{3}$ (Aggregated $\left.\mathrm{CSR}_{\mathrm{t}}\right)^{2}+\beta_{4}$ Ln Sales S $_{\mathrm{t}}+\beta_{5}$ Leverage $_{t}+\beta_{6}$ Report $_{t}+\beta_{7}$ Special_Regulation $_{t}+\beta_{7}$ Monopoly $+\beta_{8}$ ROA $_{t-1}+\varepsilon$

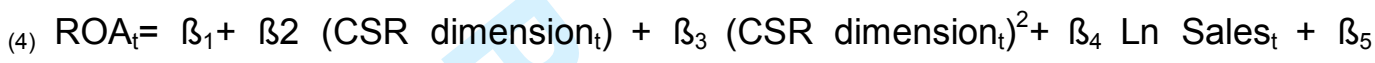
Leverage $_{t}+\beta_{6}$ Report $_{t}+\beta_{7}$ Special_Regulation $_{t}+\beta_{7}$ Monopoly $+\beta_{8}$ ROA $_{t-1}+\varepsilon$

\section{Results and discussion}

\section{Descriptive Statistics}

Figure 4 presents an overview of the evolution of the scores for each dimension (2008-2011). From that figure, we can deduce that the main concern for electric utilities companies is the environment. This obtains the best score every year. Additionally, the tendency seems to be increasing year by year, with the exception of 2009. The corporate governance score presents a similar behaviour and the employment score shows a completely opposite tendency. For the other dimensions, there is not a significant evolution during the period studied and their scores are very similar.

We report the sample descriptive statistics (Table 1) and the bivariate correlations between all the variables included in the study (Table 2). From the statistics shown in Table 1, we identify that "CSR_nw" is the CSR aggregate measure with a lower variability, while the dimensions that show a higher variability are the environmental and corporate governance ones.

As there is a considerable variation in firm size and leverage, it is necessary to include these variables in the study to control those aspects. Additionally, we find that CSR reporting is mandatory for $73 \%$ of the companies, the report only being voluntary in 10 countries (Brazil, Chile, the Czech Republic, Hong Kong, India, New Zealand, the Russian Federation, Saudi Arabia, South Korea and Switzerland). However, only three countries (Brazil, China and Poland) have a specific CSR regulation for their electric companies $(11 \%$ of the sample) and $71 \%$ of the firms operate in free markets. 
From Table 2, we observe that a significant positive correlation between the CSR aggregate measures and ROA is reported (except for the "CSR_7"). Regarding the CSR dimensions, some of them report a positive correlation with the ROA (Community, Diversity, Employment and Product Responsibility), while others show a negative one (Human Rights and Corporate Governance).

Additionally, Table 2 shows that the Human Rights dimension is highly correlated to the other CSR dimensions, so we do not include it in the CSR disaggregated models.

\section{Multivariate tests}

Our results are summarised in Tables 3 and 4. In Table 3, the regressions for the CSR aggregated measures are shown, while the results for the CSR dimension are presented in Table 4.

From Table 3, firstly, we can deduce that all the aggregated CSR measures have similar results (the coefficients and their significance) as do the adjustments of the models. Regardless of the specific CSR aggregated measure used, the results demonstrate that CSR actions have the same effect on the performance of the firms. This means that the problem is not related to the aggregation method used.

Therefore, we can deduce that the relationship is better explained by a curvilinear approach, specifically by one that is U-shaped. This means that there is an economic justification behind the highly-extraordinary or the initial behaviours although the standard actions are not as well rewarded. This could be because companies in the electrical industry are highly committed to CSR (Alonso-Almeida et al. 2013) and, consequently, they are only highly rewarded when the behaviours are exceptional or when they started to be engaged with CSR due to the high cost of not being committed (Margolis and Walsh, 2003).

Once we have tested the aggregated CSR measure models, we are going to focus on the performance output of the different CSR dimensions. At this point, we realised that each of them shows a different impact or even no influence on the FP.

Firstly, the non-existing relationship between the environment and the FP reported in both models (linear and non-linear) agrees with our hypothesis $(\mathrm{H} 2 \mathrm{a})$. These results also contrasts with previous evidence (Wagner et al., 2002; Molina-Azorín et al., 2009; Pérez-Calderón et al., 2011; Fujii et al., 2013) which defended the impact of environmental actions on the performance in multi-sectorial samples.

This leads us to confirm the distinctive purpose of the environmental actions carried out in the electrical sector since there are no rewards associated with behaving in an environmental friendly way despite being their greater concern according to Figure 4. This could be because the motivations of the environmental engagement of the electrical companies are more related to their 
need to legitimise (Deegan, 2002) and, in this way, to reverse the negative environmental impact of their regular activities (Vries et al., 2013).

Another CSR dimension shows no relationship with the performance: employment. This result disagrees with the positive linear relationship found by Deniz-Deniz and De Saa-Perez (2003) and Michelon et al. (2013) and the Ushaped one found by Sturman (2003). Due to this, we can conclude that the CSR actions oriented to employment may be carried out by the electrical companies only because of their concern about the current economic situation.

From the results of the other dimensions, we can report that CSR actions oriented to the community, diversity, corporate governance and product responsibility have an impact on the performance, so they are likely to be carried out to obtain financial rewards.

In this regard, it seems there is a positive linear relationship between the community dimension and corporate performance. This is contrary to previous evidence found by Brammer and Millington (2005), Wang et al. (2008), CabezaGarcia et al., 2010) who defended a negative relationship. Furthermore, it has to be considered that the importance of the community actions in the electrical industry is not very high. In fact, this kind of CSR actions are the next-to-last according to Figure 4.

In addition, we can report that the diversity and corporate governance dimensions display a positive linear effect on the ROA, so they are explained by the Social Impact Hypothesis. These results agree with the evidence found by Core et al. (1999) and Adams and Ferreira (2009). They argue that having a good corporate governance policy generates a better FP.

Nevertheless, another dimension' relationship is better explained by a U-shaped relationship: product responsibility - although this can be also explained by the positive-linear approach in line with lonue and Lee's (2011) results.

Finally, the tests of the control variables are statistically significant for the mandatory CSR report, the special electricity CSR regulation and the previous performance of the firm. Nevertheless, the existence of competition or monopoly in the electricity sector does not influence the relationship.

In light of these results, policy makers in some countries have to consider if publishing CSR reports should be mandatory, because in some cases this obligation may not help the CSR commitment as has been shown in our results. They should also value the positive influence of having a specific CSR regulation for the electrical sector due to its peculiarities.

\section{Conclusions}

This research aims to find out if the motivation for the socially responsible behaviour of the electrical companies is the FP associated with it, as well as to analyse if the relationship changes in the case of each CSR dimension being 
considered. That is, if the CSR actions are paying off (how those relationships are) or whether there are other motives to be carried out (legitimation, "greenwashing" or pure altruism), with a special reference to the environmental actions due to their importance in this industry.

We are able to conclude that the CSR actions are carried out by the electrical companies looking for performance rewards (in the form of profits or cost savings). Additionally, this relationship between the CSR and FP is explained by a U-shaped curve which means that the larger performance rewards are attained by the utilities companies which get the lowest and the highest CSR scores, while those with less extreme scores are not so well rewarded. In this sense, CSR behaviours are usual in this industry, therefore customers are only going to value those which are incipient (in the case of CSR actions not being carried out) or extraordinary (for those firms which have been committed to the CSR for years).

Although no significant relationship with the performance of the company has been identified, the environmental issues are the main concern of the electrical firms because they get the better scores year after year. This confirms that they are making a big effort in this area. Likewise, their environmental behaviour does not aim to gain rewards, but is rather a way to legitimise and improve the "dirty sector" image which is due to their negative environmental impacts.

On this point, the other CSR dimensions are also motivated by economic rewards. Additionally, this allows us to conclude that each CSR dimension has its own behaviour and all the hypotheses and theories developed serve to explain almost all of them. As long as diversity, corporate governance and the community present a linear relationship with the performance, the product responsibility dimension is explained by both approaches.

The contribution of this study has been to show that the motivations of the CSR engagement of the electrical companies are not always linked to "windowdressing" or improving their image, but rather are often carried out for their positive effect (via cost savings or benefits) on the financial performance of companies. In this sense, it seems that only the environmental friendly behaviours in electrical companies are motivated by that need to clean their image and in someway to reverse their negative impact.

This work highlights the need to study this relationship in other industries with some peculiarities (highest or lowest scores in a particular CSR dimension), as well as the advantages of analysing disaggregated CSR measures. This is because the motivations of each aspect or dimension could be completely different among them and regarding CSR aggregated measures.

Additionally, our results could be used by the managers of companies to know which the most strategic and worthwhile CSR actions are and take them into consideration in their decision-making processes in accordance with their priorities. 
As a limitation of the paper, we should not forget that it has been based on the information disclosed by companies, and it would be a challenge in the future to study whether this agrees with the real actions carried out by them. Finally, the results obtained are hardly comparable, except in the case of some industries with many similarities to the electrical utilities. 


\section{REFERENCES}

Adams RB, Ferreira D. 2009. Women in the boardroom and their impact on governance and performance. Journal of Financial Economics 94(2): 291-309.

Allouche J, Laroche P. 2005. A meta-analytical investigation of the relationship between Corporate Social and Financial Performance. Revue de Gestion des Resources Humaines 57: 18-41.

Alonso-Almeida MM, Llach J, Marimon F. 2013. A Closer Look at the 'Global Reporting Initiative' Sustainability Reporting as a Tool to Implement Environmental and Social Policies: A Worldwide Sector Analysis. Corporate Social Responsibility and Environmental Management. doi: 10.1002/csr.1318

Andres PD, Vallelado E. 2008. Corporate governance in banking: The role of the board of directors. Journal of Banking \& Finance 32(12): 2570-2580.

Barnett ML, Salomon RM. 2012. Does it pay to be really good? Addressing the shape of the relationship between social and financial performance. Strategic Management Journal 33: 1304-1320. doi: 10.1002/smj.1980

Beurden P, Gössling T. 2008. The Worth of Value - A Literature Review on the Relation Between Corporate Social and Financial Performance. Journal of Business Ethics 82: 407-424.

Bird R, Hall AD, Momentè F, Reggiani F. 2007. What corporate social responsibility activities are valued by the market? Journal of Business Ethics 76(2): 189-206.

Brammer S, Millington A. 2005. Corporate reputation and philanthropy: An empirical analysis. Journal of Business Ethics 61(1): 29-44.

Cabeza-García L, Martínez-Campillo A, Marbella-Sánchez F. 2010. Análisis de la relación entre los resultados sociales y económicos de las cajas de ahorros españolas: un caso de responsabilidad social corporativa. Innovar 20(37): 33-46.

Cai Y, Jo H, Pan C. 2012. Doing well while doing bad? CSR in controversial industry sectors. Journal of Business Ethics 108(4): 467-480. DOI: 10.1007/s10551-011-11037.

Capar N, Kotabe M. 2003. The relationship between international diversification and performance in service firms. Journal of International Business Studies 34(4): 345-355. doi:10.1057/palgrave.jibs.8400036

Carroll AB, Shabana KM. 2010. The Business Case for Corporate Social Responsibility: A Review of Concepts, Research and Practice. International Journal of Management Reviews 12(1): 85-105.

Chin WW. 2010. How to write up and report PLS analyses. In Handbook of partial least squares: Concepts, methods and applications, Esposito Vinzi V, Chin WW, Henseler J, Wang H. (Eds.). Springer-Verlag: Berlin.

Clarkson MBE. 1995. A stakeholder framework for analyzing and evaluating corporate social performance. Academy of Management Review 20(1): 92-117.

Core JE, Holthausen RW, Larcker DF. 1999. Corporate governance, chief executive officer compensation, and firm performance. Journal of Financial Economics 51(3): 371-406.

Davidson WN, Worrell DL. 1990. A Comparison and Test of the Use of Accounting and Stock Market Data in Relating Corporate Social Responsibility and Financial Performance. Akron Business and Economic Review 21(3): 7-19. 
Dawkins CE, Fraas JW. 2010. Beyond Acclamations and excuses: environmental performance, voluntary environmental disclosure, and the role of visibility. Journal of Business Ethics 92(4): 655-655.

Déniz-Déniz M, De Saá-Pérez P. 2003. A resource-based view of corporate responsiveness toward employees. Organization Studies 24(2): 299-319.

Deegan C, Gordon B. 1996. A study of the environmental disclosure practices of Australian corporations. Accounting and Business Research 26(3): 187-199.

Deegan C. 2002. Introduction: The legitimising effect of social and environmental disclosures-a theoretical foundation. Accounting, Auditing \& Accountability Journal 15(3): 282-311.

Ducassy I. 2013. Does Corporate Social Responsibility Pay Off in Times of Crisis? An Alternate Perspective on the Relationship between Financial and Corporate Social Performance. Corporate Social Responsibility and Environmental Management 20:157-167. doi:10.1002/csr.1282

Endrikat J, Guenther E, Hoppe H. 2014. Making sense of conflicting empirical findings: A meta-analytic review of the relationship between corporate environmental and financial performance. European Management Journal (in press).http://dx.doi.org/10.1016/j.emj.2013.12.004

Escobar B, Miras MM. 2013. Spanish Savings Banks' Social Commitment: just pretty words? Social Responsibility Journal 9(3): 427-440. DOI: .

Fernández JL, Luna L. 2007. The creation of value through corporate reputation. Journal of Business Ethics 76(3): 335-346.

Fifka MS. 2013. Corporate Responsibility Reporting and its Determinants in Comparative Perspective - a Review of the Empirical Literature and a Meta-analysis. Business Strategy and the Environment, 22: 1-35. doi: 10.1002/bse.729

Francoeur C, Labelle R, Sinclair-Desgagné B. 2008. Gender Diversity in Corporate Governance and Top Management. Journal of Business Ethics 81: 83-95.

Freeman RE. 1984. Strategic Management: A Stakeholder Approach. Boston, Pitman.

Friedman M. 1970. The Social Responsibility of Business is to Increase Its Profits. New York Times, 13, September 1970, 122-126.

Fujii H, Iwata K, Kaneko S, Managi S. 2013. Corporate Environmental and Economic Performance of Japanese Manufacturing Firms: Empirical Study for Sustainable Development. Business Strategy and the Environment 22: 187-201. doi: 10.1002/bse.1747

Garriga E, Melé D. 2004. Corporate Social Responsibility Theories: Mapping the Territory. Journal of Business Ethics 53: 51-71.

Godfrey PC, Hatch NW. 2007. Researching corporate social responsibility: an agenda for the 21st century. Journal of Business Ethics 70: 87- 98.

Gray R, Javad M, Power DM, Sinclair CD. 2001. Social and environmental disclosure and corporate characteristics: a research note and extension. Journal of Business Finance \& Accounting 28(3-4): 327-356.

Griffin JJ, Mahon JF. 1997. The corporate social performance and corporate financial performance debate: Twenty-five years of incomparable research. Business and Society 36: 5-31.

Guenster N, Bauer R, Derwall J, Koedijk K. 2011. The Economic Value of Corporate Eco-Efficiency. European Financial Management 17(4): 679-704. 
Hackston D, Milne MJ. 1996. Some determinants of social and environmental disclosures in New Zealand companies. Accounting, Auditing and Accountability Journal 9(1): 77 - 108.

Hillman AJ, Keim GD. 2001. Shareholder value, stakeholder management, and social issues: what's the bottom line? Strategic Management Journal 22(2): 125-139.

Inoue Y, Lee S. 2011. Effects of different dimensions of corporate social responsibility on corporate financial performance in tourism-related industries. Tourism Management 32(4): $790-804$.

loannou I, Serafeim G. 2012. What drives corporate social performance? The role of nation-level institutions. Journal of International Business Studies 43(9): 834-864. doi:10.1057/jibs.2012.26.

Kang KH, Lee S, Huh C. 2010. Impacts of positive and negative corporate social responsibility activities on company performance in the hospitality industry. International Journal of Hospitality Management 29(1): 72-82.

Kerckhoffs T, Wilde-Ramsing J. 2010. European Works Councils and Corporate Social Responsibility in the European Energy Sector. Stichting Onderzoek Multionationale Ondernemingen: Netherlands.

Lankoski L. 2008. Corporate responsibility activities and economic performance: a theory of why and how they are connected. Business Strategy and the Environment 17: $536-547$. doi: 10.1002/bse.582

Lee MDP. 2008. A review of the theories of corporate social responsibility: Its evolutionary path and the road ahead. International Journal of Management Reviews 10(1): 53-73.

Lee L, Petter S, Fayard D, Robinson S. 2011. On the use of partial least squares path modeling in accounting research. International Journal of Accounting Information Systems 12(4): 305-328.

Margolis JD, Walsh JP. 2003. Misery loves companies: Rethinking social initiatives by business. Administrative Science Quarterly 48(2): 268-305.

Marom IY. 2006. Toward a Unified Theory of the CSP-CFP Link. Journal of Business Ethics, 67: 191-200. DOI: 10.1007/s10551-006-9023-7.

Martínez-Ferrero J, García-Sanchez IM, Cuadrado-Ballesteros B. 2013. Effect of Financial Reporting Quality on Sustainability Information Disclosure. Corporate Social Responsibility and Environmental Management. doi:10.1002/csr.1330

McWilliams A, Siegel D. 2000. Corporate social responsibility and financial performance: correlation or misspecification? Strategic Management Journal 21(5): 603-609. doi: 10.1002/(SICI)1097-0266(200005)21:5<603::AID-SMJ101>3.0.CO;2-3

McWilliams A, Siegel D. 2001. Corporate Social Responsibility: A Theory of the Firm Perspective. Academy of Management Review 26(1): 117-127.

Melo T, Garrido-Morgado A. 2012. Corporate Reputation: A Combination of Social Responsibility and Industry. Corporate Social Responsibility and Environmental Management 19(1): 11-31. doi: 10.1002/csr.260

Michelon G, Boesso G, Kumar K. 2013. Examining the Link between Strategic Corporate Social Responsibility and Company Performance: An Analysis of the Best Corporate Citizens. Corporate Social Responsibility and Environmental Management 20: 81-94. DOI: 10.1002/csr.1282 
Mio C. 2010. Corporate social reporting in Italian multi-utility companies: an empirical analysis. Corporate Social Responsibility and Environmental Management 17(5): 247271. doi: $10.1002 / \mathrm{csr} .213$

Mobus JL. 2005. Mandatory environmental disclosures in a legitimacy theory context. Accounting, Auditing \& Accountability Journal 18(4): 492-517.

Molina-Azorín JF, Claver-Cortés E, López-Gamero MD, Tarí JJ. 2009. Green management and financial performance: a literature review. Management Decision 47(7): 1080-1100.

Moskowitz MR. 1972. Choosing Socially Responsible Stocks. Business and Society Review 1: 71-75.

Orlitzky M, Schmidt FL, Rynes SL. 2003. Corporate Social and Financial Performance: A Meta-analysis. Organization Studies 24: 403-441.

Pätäri S, Jantunen A, Kyläheiko K, Sandström J. 2012. Does Sustainable Development Foster Value Creation? Empirical Evidence from the Global Energy Industry. Corporate Social Responsibility and Environmental Management 19:317-326. doi: 10.1002/csr.280.

Patten DM. 2002. The relation between environmental performance and environmental disclosure: a research note. Accounting, Organizations and Society 27(8): 763-773. http://dx.doi.org/10.1016/S0361-3682(02)00028-4

Peloza J. 2006. Using corporate social responsibility as insurance for financial performance. California Management Review 48(2): 52-72.

Peloza J. 2009. The challenge of measuring financial impacts from investments in corporate social performance. Journal of Management 35(6): 1518-1541. doi: $10.1177 / 0149206309335188$

Pérez-Calderón E, Milanés-Montero P, Ortega-Rossell FJ. 2012. Environmental Performance and Firm Value: Evidence from Dow Jones Sustainability Index Europe. International Journal of Environmental Reseach 6(4): 1007-1014.

Pérez-Ruiz A, Rodríguez-Bosque IR. 2012. La imagen de Responsabilidad Social Corporativa en un contexto de crisis económica: El caso del sector financiero en España. Universia Business Review 33: 14-29.

Porter ME, Van der Linde C. 1995. Green and competitive: ending the stalemate. Harvard Business Review 73(5): 120-134.

Preston LE, O'Bannon DP. 1997. The Corporate Social-Financial Performance Relationship: A Typology and Analysis. Business and Society 36: 419-429.

Roldán JL, Sánchez-Franco MJ. 2012. Variance-based structural equation modeling: guidelines for using partial least squares in information systems research. In Research Methodologies, Innovations and Philosophies in Software Systems Engineering and Information Systems, Mora M, Gelman O, Steenkamp AL, Raisinghani M. (eds). IGI Global: USA.

Rowley T, Berman S. 2000. A brand new brand of corporate social performance. Business \& Society 39(4): 397-418. doi: 10.1177/000765030003900404

Ruf BM, Muralidhar K, Brown RM, Janney JJ, Paul K. 2001. An Empirical Investigation of the Relationship Between Change in Corporate Social Performance and Financial Performance: A Stakeholder Theory Perspective. Journal of Business Ethics 32: 143156. 
Salzmann O, lonescu-Somers A, Steger U. 2005. The Business Case for Corporate Sustainability: Literature Review and Research Options. European Management Journal 23: 27-36.

Schaltegger S, Synnestvedt T. 2002. The link between 'green' and economic success: environmental management as the crucial trigger between environmental and economic performance. Journal of Environmental Management 65(4): 339-346.

Schultz F, Wehmeier S. 2010. Institutionalization of corporate social responsibility within corporate communications: Combining institutional, sensemaking and communication perspectives. Corporate Communications: An International Journal 15(1): 9-29.

Simpson GW, Kohers T. 2002. The link between Corporate Social and Financial Performance: Evidence from the Banking Industry. Journal of Business Ethics 35: 97109.

Sturman MC. 2003. Searching for the inverted U-shaped relationship between time and performance: Meta-analyses of the experience/performance, tenure/performance, and age/performance relationships. Journal of Management 29(5): 609-640.

Surroca J, Tribó J, Waddock S. 2010. Corporate Responsibility and Financial Performance: the role of Intangible Resources. Strategic Management Journal 31: 463490.

Sutton CN. 2007. The role of the utilities sector in expanding economic opportunity. Economic Opportunities Series. Harvard University, Cambridge (USA).

Vries G, Terwel BW, Ellemers N, Daamen DDL. 2013. Sustainability or Profitability? How Communicated Motives for Environmental Policy Affect Public Perceptions of Corporate Greenwashing. Corporate Social Responsibility and Environmental Management. doi: 10.1002/csr.1327

Waddock SA, Graves SB. 1997. The corporate social performance-financial performance link. Strategic Management Journal 8(4): 303-319.

Wagner M, Van Phu N, Azomahou T, Wehrmeyer W. 2002. The relationship between the environmental and economic performance of firms: an empirical analysis of the European paper industry. Corporate Social Responsibility and Environmental Management 9(3): 133-146.

Waldman DA, Siegel DS, Javidan M. 2006. Components of CEO Transformational Leadership and Corporate Social Responsibility. Journal of Management Studies 43(8): 1703-1725.

Wang $\mathrm{H}$, Choi J, Li J. 2008. Too little or too much? Untangling the relationship between corporate philanthropy and firm financial performance. Organization Science 19(1): 143-159.

Wu ML. 2006. Corporate Social Performance, Corporate Financial Performance and Firm Size. Journal of American Academy of Business 8(1): 163- 171. 
Table 1: Descriptive statistics

7

8

\begin{tabular}{|l|r|r|r|}
\hline N & Mean & \multicolumn{1}{|c|}{$\begin{array}{r}\text { Standard } \\
\text { deviation }\end{array}$} \\
\hline CSR_nw & 356 & 40.57 & 3.967 \\
CSR_2 & 356 & 60.67 & 26.330 \\
CSR_5 & 355 & 54.28 & 5.448 \\
CSR_7 & 356 & 54.09 & 6.656 \\
\hline \hline Environmental & 356 & 62.82 & 24.535 \\
Community & 356 & 51.56 & 0.232 \\
Diversity & 356 & 52.01 & 0.989 \\
Employment & 356 & 54.07 & 7.363 \\
Product_responsibility & 356 & 51.07 & 0.524 \\
Human_rights & 356 & 52.68 & 0.336 \\
Corporate_governance & 356 & 54.43 & 30.791 \\
Sales & 353 & $65 \mathrm{e}+08$ & $4.02 \mathrm{e}+09$ \\
Leverage & 353 & 138.64 & 104.062 \\
Report & 356 & 0.27 & 0.444 \\
Special_regulation & 356 & 0.11 & 0.316 \\
Monopoly & 356 & 0.29 & 0.455 \\
RoA & 340 & 47.53 & 13.521 \\
\hline
\end{tabular}


Table 2: Bivariate correlations

\begin{tabular}{|c|c|c|c|c|c|c|c|c|c|c|c|c|c|c|c|c|c|}
\hline & (1) & (2) & (3) & (4) & (5) & (6) & (7) & (8) & (9) & (10) & (11) & $(12)$ & (13) & $(14)$ & $(15)$ & (16) & $(17)$ \\
\hline (1) CSR_nw & 1 & & & & & & & & & & & & & & & & \\
\hline (2) CSR_2 & $0,91^{* *}$ & 1 & & & & & & & & & & & & & & & \\
\hline (3) CSR_5 & $0,99^{*}$ & $0,91^{* *}$ & 1 & & & & & & & & & & & & & & \\
\hline (4) CSR_7 & $0,77^{* *}$ & $0,73^{* *}$ & $0,77^{* *}$ & 1 & & & & & & & & & & & & & \\
\hline (5) Environmental & $0,95^{*}$ & $0,92^{* *}$ & $0,966^{* *}$ & $0,77^{*}$ & 1 & & & & & & & & & & & & \\
\hline (6) Community & $0,27^{* *}$ & $0,24^{* *}$ & $0,26 *$ & $0,11^{*}$ & $0,17^{* *}$ & 1 & & & & & & & & & & & \\
\hline (7) Diversity & $0,15^{*}$ & 0,08 & $0,14^{* *}$ & $-0,01$ & 0,05 & $0,38^{* *}$ & 1 & & & & & & & & & & \\
\hline (8) Employment & $0,51^{*}$ & $0,32^{* *}$ & $0,48^{* *}$ & $0,29^{* *}$ & 0,22 & $0,31^{* *}$ & $0,20^{*}$ & 1 & & & & & & & & & \\
\hline (9) Product_responsibility & $-0,04$ & $-0,06$ & $-0,04$ & $-0,16^{* \prime}$ & $-0,07$ & $0,21^{* *}$ & 0,06 & $-0,01$ & 1 & & & & & & & & \\
\hline (10) Human_rights & $-0,38^{* \prime}$ & $-0,36^{* *}$ & $-0,37^{* *}$ & $-0,17^{* *}$ & $-0,27 *$ & $-0,55^{* *}$ & $-0,35^{* *}$ & $-0,36^{* \prime}$ & $-0,41^{* *}$ & 1 & & & & & & & \\
\hline (11)Corporate_governance & $0,28^{* \prime}$ & $0,29^{* *}$ & $0,29^{* *}$ & $0,83^{* *}$ & $0,32^{* *}$ & $-0,06$ & $-0,13^{*}$ & 0,02 & $-0,20^{* *}$ & 0,05 & 1 & & & & & & \\
\hline (12) Sales & 0,08 & 0,10 & 0,08 & $-0,07$ & 0,09 & $0,13^{*}$ & $-0,07$ & $-0,01$ & $-0,06$ & $-0,08$ & $-0,17^{*}$ & 1 & & & & & \\
\hline (13) Leverage & $-0,09$ & $-0,11^{*}$ & $-0,09$ & $-0,03$ & $-0,09$ & $-0,02$ & 0,06 & $-0,04$ & 0,06 & 0,01 & 0,03 & $-0,06$ & 1 & & & & \\
\hline (14) Report & $-0,03$ & 0,02 & $-0,04$ & $-0,35^{* *}$ & $-0,08$ & 0,08 & $0,14^{* *}$ & 0,09 & $0,11^{*}$ & $-0,11^{\circ}$ & $-0,49^{* *}$ & $0,22^{* *}$ & $-0,34^{* *}$ & 1 & & & \\
\hline (15) Special_regulation & $-0,00$ & $-0,03$ & $-0,01$ & $-0,23^{* *}$ & $-0,07$ & $0,13^{*}$ & $0,32^{* *}$ & $0,14^{* *}$ & 0,09 & $-0,10$ & $-0,33^{* \prime}$ & $-0,05$ & 0,07 & $0,19^{* \prime}$ & 1 & & \\
\hline (16) Monopoly & $0,11^{*}$ & $0,14^{\star *}$ & $0,12^{*}$ & $0,14^{\star *}$ & $0,14^{\star *}$ & 0,02 & 0,00 & $-0,03$ & $-0,04$ & $-0,11^{*}$ & $0,12^{*}$ & $0,13^{*}$ & 0,01 & 0,06 & 0,01 & 1 & \\
\hline (17) ROA & $0,16^{* *}$ & $0,11^{*}$ & $0,15^{* *}$ & $-0,02$ & 0,03 & $0,39^{* *}$ & $0,36^{* *}$ & $0,33^{* *}$ &, $28^{* *}$ & $-0,39^{* *}$ & $-0,15^{\star *}$ & 0,03 & $-0,11$ & $0,39^{* *}$ & $0,25^{\star *}$ & $-0,04$ & 1 \\
\hline
\end{tabular}


Table 3: CSR aggregated models

\begin{tabular}{|c|c|c|c|c|c|c|c|c|}
\hline \multirow{3}{*}{$\begin{array}{c}\begin{array}{c}\text { Independent } \\
\text { Variables }\end{array} \\
\text { Constant }\end{array}$} & \multicolumn{8}{|c|}{ Dependent Variable } \\
\hline & \multicolumn{8}{|c|}{ ROA } \\
\hline & 18.155 ** & 150.316 * & $30.624 * * *$ & $34.460 * * *$ & $18.816^{* *}$ & $147.869 *$ & $19.298^{* *}$ & 98.055 ** \\
\hline $\begin{array}{l}\text { CSR_nw } \\
\left(C S R \_n w\right)^{2} \\
\text { CSR_2 } \\
\left(C S R \_2\right)^{2} \\
\text { CSR_5 } \\
\left(C S R \_5\right)^{2} \\
\text { CSR_7 } \\
\left(C S R \_7\right)^{2}\end{array}$ & 0.397 * & $\begin{array}{c}-6.339 \text { * } \\
0.084 \text { * }\end{array}$ & 0.051 * & $\begin{array}{l}-0.189 \\
\mathbf{0 . 0 0 2 \dagger}\end{array}$ & 0.283 * & $\begin{array}{r}-4.644 * \\
0.046 *\end{array}$ & 0.236 * & $\begin{array}{r}-2.779 \text { * } \\
0.028 \text { * }\end{array}$ \\
\hline Ln Sales & $-0.570 \dagger$ & -0.467 & -0.557 & -0.423 & $-0.569+$ & -0.469 & -0.479 & -0.446 \\
\hline Leverage & -0.004 & -0.004 & -0.004 & -0.003 & -0.004 & -0.004 & -0.005 & -0.004 \\
\hline Report & $7.869 * * *$ & $8.117 * * *$ & $7.487 * * *$ & $7.768 * * *$ & $7.854^{* * *}$ & $8.139 * * *$ & $8.325 * * *$ & $8.579 * * *$ \\
\hline Special regulation & 5.533 * & 5.428 * & 5.658 * & 5.788 * & 5.559 * & 5.478 * & $6.319 * * *$ & $6.542 * * *$ \\
\hline Monopoly & -0.418 & -0.617 & -0.391 & -0.747 & -0.422 & -0.632 & -0.219 & -0.239 \\
\hline $\operatorname{ROA}_{t-1}$ & 0.424 *** & $0.415^{* * *}$ & $0.431^{* * *}$ & 0.416 *** & 0.426 *** & $0.416 * * *$ & $0.433 * * *$ & $0.428 * * *$ \\
\hline Wald Test & $201.63^{* * *}$ & $208.00 * * *$ & $197.94^{* * *}$ & $202.84^{* * *}$ & $201.13^{* * *}$ & $207.75^{* * *}$ & $200.12^{* * *}$ & $207.74 * * *$ \\
\hline
\end{tabular}


Table 4: CSR disaggregated models

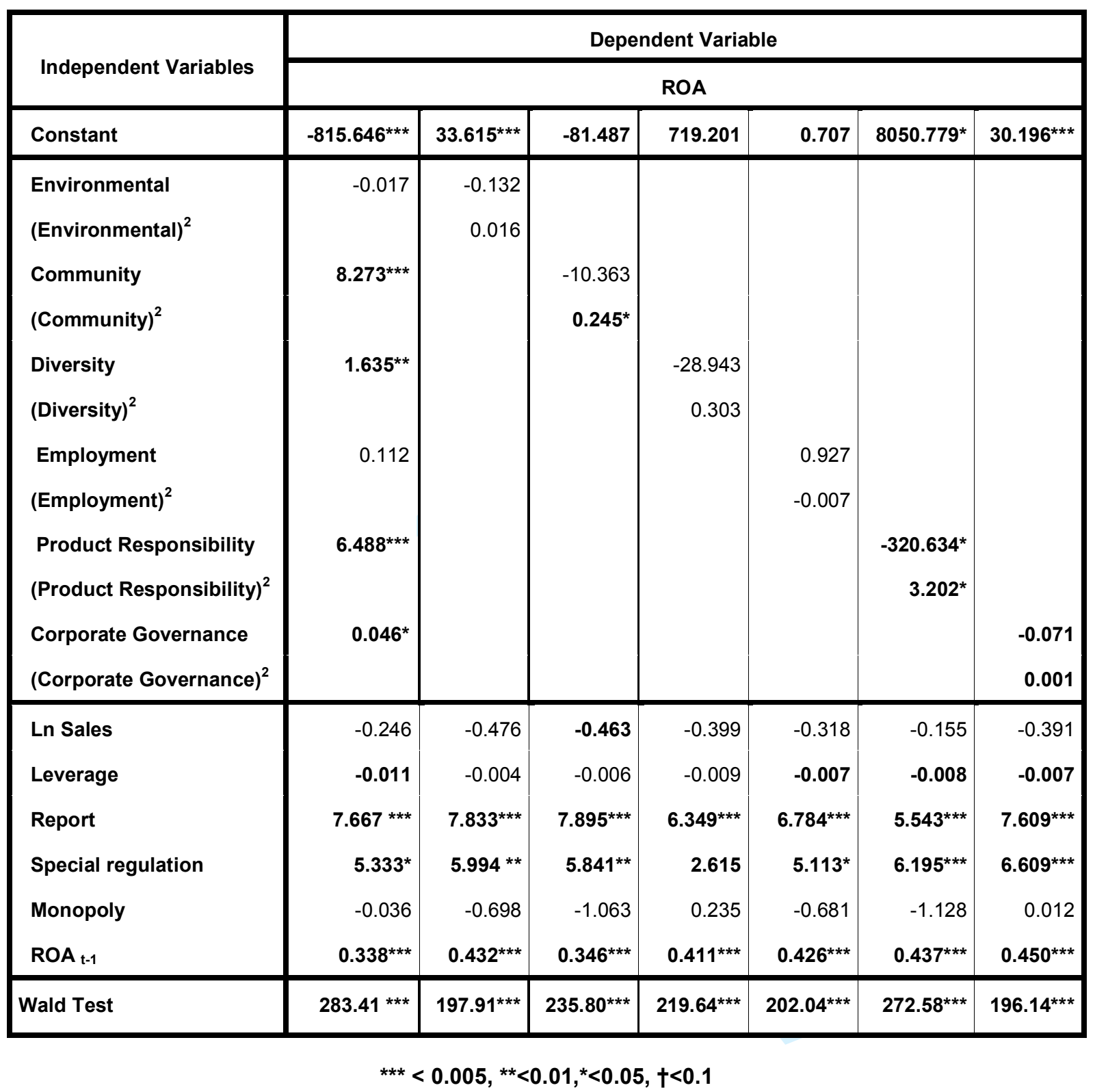


APPENDIX 1

\begin{tabular}{|c|c|c|}
\hline A2a & Edison Intertiol & Ormat Techs. \\
\hline Acea & Edp Energias De Portugal & Pepco Holdings \\
\hline Aes & Edp Renovaveis & Pg\&E \\
\hline Aes Tiete On & Electric Power Development & Pincle West Capital \\
\hline Power And & Eletrobras On & Pka.Grupa Energetycz \\
\hline Utilities & Elia System Operator & Power Assets Holdings \\
\hline Alliant Energy Corporation & Emera & Power Grid Corporation Of \\
\hline Alpiq Holding & Endesa & India \\
\hline American Electric Power & Endesa & Ppl \\
\hline Areva & Enel & Public Power \\
\hline Atlantic Power & Eneray World & Public Service Enterprise \\
\hline $\begin{array}{l}\text { Beijing Datang Power } \\
\text { Brookfield Renewable } \\
\text { Energy Partners }\end{array}$ & $\begin{array}{l}\text { Enersis } \\
\text { Entergy }\end{array}$ & $\begin{array}{l}\text { Group } \\
\text { Red Electrica Corporacion } \\
\text { Reliance Infrastructure }\end{array}$ \\
\hline Calpine & Exelon & $\begin{array}{l}\text { Reliance } \\
\text { Rosseti }\end{array}$ \\
\hline Cemig On & Fed.Grid Co.Of Ung.Sy & Rushydro \\
\hline Cez & Firstenergy & Saudi Electricity \\
\hline Cheung Kong Infrastructure & Fortis & Shikoku Electric Power \\
\hline Holdings & Fortum & Southern \\
\hline China Resources Power & Great Plains Energy & Sp Ausnet \\
\hline Chi Yangtze Pwr. 'A & Hawaiian Electric Industries & Spark Infrastructure Group \\
\hline Clp Holdings & Huaneng Power Intertiol 'A' & Tata Power \\
\hline Cms Energy & Iberdrola & Teco Energy \\
\hline Consolidated Edison & Infigen Energy & Tega Siol \\
\hline Contact Energy & Itc Holdings & Ter Rete Elettrica Z \\
\hline Cpfl Energia On & Korea Electric Power & Tractebel On \\
\hline ol Power & Mvv Energie & Transalta \\
\hline Generation ' $\mathrm{H}$ ' & Nextera Energy & Verbund \\
\hline Dominion Resources & Northeast Utilities & Westar En. \\
\hline Dte Energy & Northland Power & Xcel Energy \\
\hline Dynegy & Nrg Energy & \\
\hline E On Russia & Ntpc & \\
\hline Edf & Nv Energy & \\
\hline
\end{tabular}




\begin{tabular}{|c|c|c|}
\hline $\begin{array}{c}\text { CSR } \\
\text { DIMENSION }\end{array}$ & \multicolumn{2}{|c|}{ INDICATORS OR DEFINITIONS } \\
\hline COMMUNITY & $\begin{array}{l}\text { 1. Bribery Corruption and Fraud } \\
\text { Controversies } \\
\text { 2. Business Ethics Compliance } \\
\text { 3. Corporate Responsibility Awards } \\
\text { 4. Crisis Management } \\
\text { 5. Critical Countries - Indigenous } \\
\text { People Controversies }\end{array}$ & $\begin{array}{l}\text { 6. Donations in General } \\
\text { 7. Implementation } \\
\text { 8. Improvements } \\
\text { 9. Monitoring } \\
\text { 10. Patent Infringement } \\
\text { 11. Policy } \\
\text { 12. Total donations. }\end{array}$ \\
\hline DIVERSITY & $\begin{array}{l}\text { 1. Diversity Compliance } \\
\text { 2. Diversity Controversies } \\
\text { 3. Family Friendly } \\
\text { 4. Implementation } \\
\text { 5. Improvements }\end{array}$ & $\begin{array}{l}\text { 6. Management Equal } \\
\text { Opportunity } \\
\text { 7. Managers female ratio } \\
\text { 8. Monitoring } \\
\text { 9. Policy } \\
\text { 10. Work-Life Balance }\end{array}$ \\
\hline $\begin{array}{l}\text { EMPLOYMENT } \\
\text { QUALITY }\end{array}$ & $\begin{array}{l}\text { 1. Announced Lay-offs } \\
\text { 2. Bonus Plan } \\
\text { 3. Employment Awards } \\
\text { 4. Generous Fringe Benefits. } \\
\text { 5. Implementation } \\
\text { 6. Improvements } \\
\text { 7. Key management departure. } \\
\text { 8. Monitoring } \\
\text { 9. Net Employment Creation }\end{array}$ & $\begin{array}{l}\text { 10. Personnel Turnover. } \\
\text { 11. Policy } \\
\text { 12 Salaries } \\
\text { 13. Salaries Distribution } \\
\text { 14. Salary gap } \\
\text { 15. Strikes } \\
\text { 16. Trade Union } \\
\text { Representant } \\
\text { 17. Wages or Working } \\
\text { Condition Controversies }\end{array}$ \\
\hline HUMAN RIGHTS & $\begin{array}{l}\text { 1.Child Labor Controversies } \\
\text { 2. Freedom of Association } \\
\text { Controversies } \\
\text { 3. Human Rights Controversies } \\
\text { 4. Implementation }\end{array}$ & $\begin{array}{l}\text { 5. Improvements } \\
\text { 6. Monitoring } \\
\text { 7. Policy } \\
\text { 8. Suppliers Social Impact }\end{array}$ \\
\hline $\begin{array}{c}\text { PRODUCT } \\
\text { RESPONSIBILITY }\end{array}$ & $\begin{array}{l}\text { 1. Customers Controversies } \\
\text { 2. Implementation } \\
\text { 3. Improvements } \\
\text { 4. Monitoring } \\
\text { 5. Policy } \\
\text { 6. Product Access }\end{array}$ & $\begin{array}{l}\text { 7. Product Compliance } \\
\text { 8. Quality Management } \\
\text { 9. Social Exclusion } \\
\text { Controversies } \\
\text { 10. Technology Know-How } \\
\text { Sharing }\end{array}$ \\
\hline ENVIRONMENT & $\begin{array}{l}\text { The environmental pillar measures } \\
\text { non-living natural systems, includin } \\
\text { as complete ecosystems }\end{array}$ & $\begin{array}{l}\text { mpany's impact on living and } \\
\text { air, land and water, as well }\end{array}$ \\
\hline $\begin{array}{l}\text { CORPORATE } \\
\text { GOVERNANCE }\end{array}$ & $\begin{array}{l}\text { The corporate governance pillar me } \\
\text { processes, which ensure that its b } \\
\text { in the best interests of its long term }\end{array}$ & $\begin{array}{l}\text { ires a company's systems and } \\
\text { members and executives act } \\
\text { reholders }\end{array}$ \\
\hline
\end{tabular}




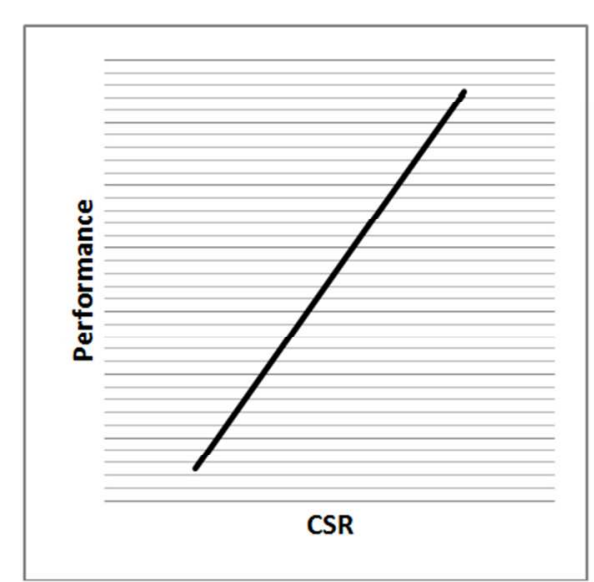

Figure 1.a. Social Impact Hypothesis

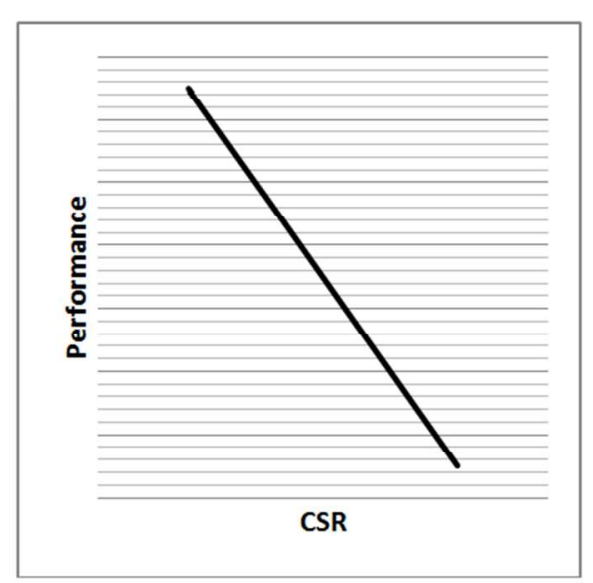

Figure 1.b. Trade-Off Hypothesis

Figure 1: Lineal approach of CSR-performance relationship. $238 \times 129 \mathrm{~mm}(96 \times 96 \mathrm{DPI})$ 


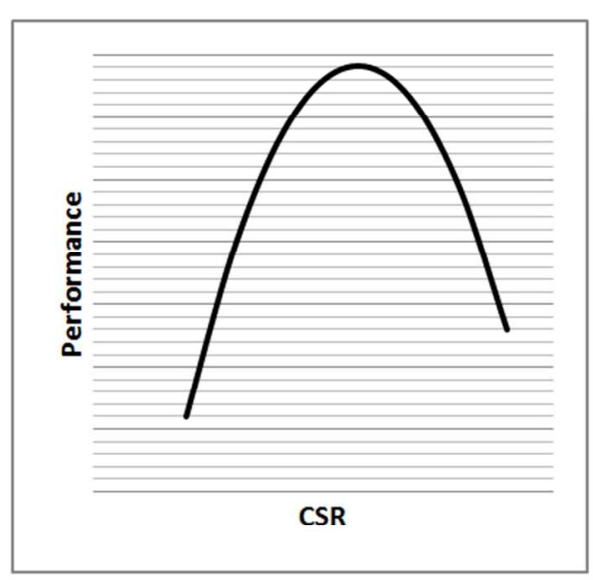

Figure 2.a. Inverted U-shaped

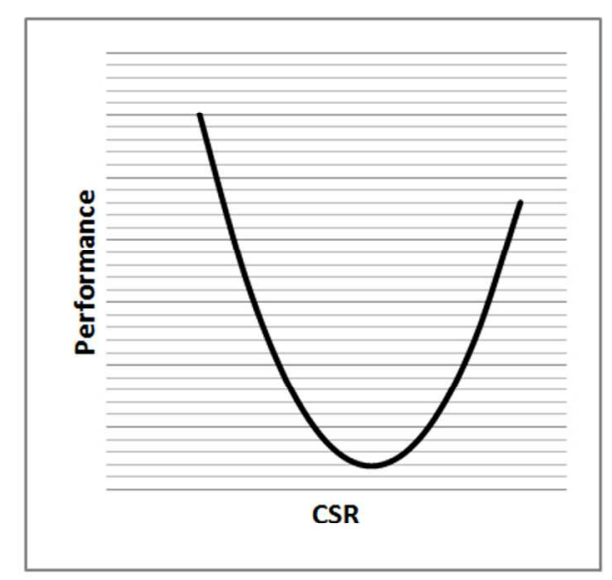

Figure 2.b. U-shaped

Figure 2: Non-lineal approach of CSR-performance relationship. $236 \times 124 \mathrm{~mm}$ (96 x 96 DPI) 


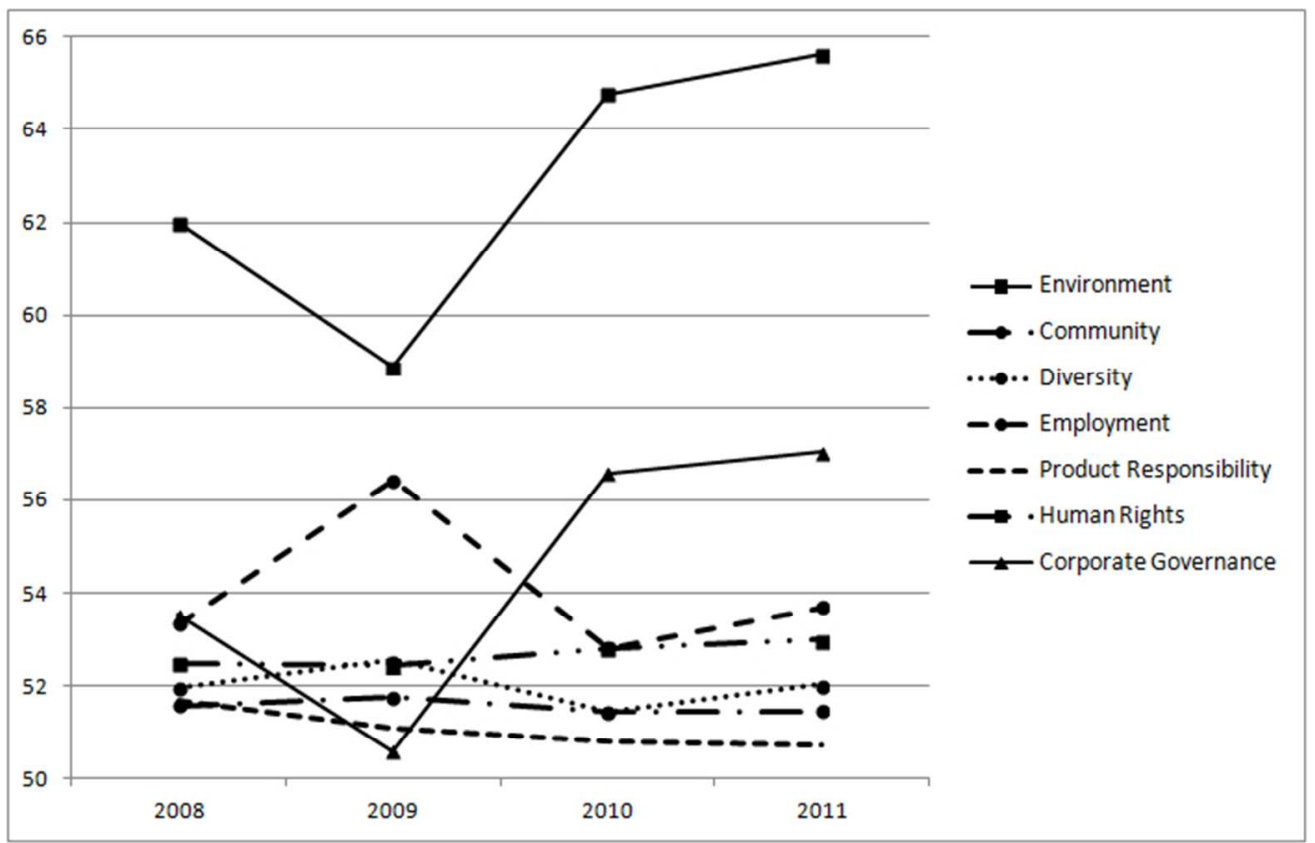

Figure 4: Evolution of the scores for each CSR dimension $186 \times 121 \mathrm{~mm}(96 \times 96 \mathrm{DPI})$ 